\title{
Different Seaweeds Use for Iodine Deficiency Overcome
}

\author{
Sónia Ferraz ${ }^{* 1}$, Carla Ragonezi ${ }^{1}$, Nuno Nunes ${ }^{1,2}$, Sofia Valente ${ }^{1}$ and Miguel AA Pinheiro de Carvalho ${ }^{1,3}$ \\ ${ }^{1}$ ISOPlexis Genebank, University of Madeira, Campus da Penteada, 9050-290 Funchal, Madeira, Portugal. \\ ${ }^{2} U B Q$ II, Unidade de Bioquímica, Lda. Rua Visconde de Anadia, Edifício Anadia 5Andar CC, 9050-020 Funchal,Madeira, Portugal. \\ ${ }^{3}$ ICAAM, University of Évora, Apartado 94, 7006-554 Évora, Portugal.
}

*Corresponding author: Sónia Ferraz, ISOPlexis Genebank, University of Madeira, Campus da Penteada, 9050-290 Funchal,

Madeira, Portugal

\section{ARTICLE INFO}

Received: 幽 February 21, 2019

Published: 慧 March 05, 2019

Citation: Sónia Ferraz, Carla Ragonezi, Nuno Nunes, Sofia Valente, Miguel AA Pinheiro de Carvalho. Different Seaweeds Use for Iodine Deficiency Overcome. Biomed J Sci \& Tech Res 15(3)2019. BJSTR. MS.ID.002710.

Keywords: Iodine Deficiency Disorders (Idd); Algae; Supplementation
ABSTRACT

Iodine deficiency is one of the three most common nutritional deficiencies worldwide and is a global public health problem that affects particularly the young children, pregnant women and elderly. The consequences of iodine deficiency disorder (IDD) include goiter and cretinism. The traditional consumption of iodine via supplemented salt should be monitored to reduce population sodium intake due to hypertension problems and the uncertain bioavailability of iodine in the supplemented salt. One approach for an effective and cost-efficient iodine supplementation is the use of seaweeds in food intake. Seaweeds, among all foods, are the most famous and reliable source of natural iodine. In this minireview we pretend to explore the different uses of seaweeds to fill the iodine deficiency and improve life quality.

Abbreviations: T3: Triiodothyronine; T4: Thyroxine; WHO: World Health Organization; FAO: Food and Agriculture Organization; IDD: Iodine Deficiency Disorders

\section{Introduction}

Iodine is an essential mineral that is vital for the synthesis of thyroid hormones, triiodothyronine (T3) and thyroxine (T4), which play key roles in metabolism [1] including the increase of protein synthesis, improvement of metabolic activity promotion of growth and maintenance of normal brain function [2]. Iodine deficiency can cause among others per example, goiter, hypothyroidism, cretinism, deaf-mutism, mental retardation, congenital anomalies [3]. The most susceptible groups for iodine deficiency are young children, pregnant women and women that are breastfeeding, besides, in some situations, represents a significant hazard to national, social and economic development [4,5]. Based on the proportion of the population that presents urinary iodine $<100 \mu \mathrm{g} / \mathrm{L}$ (clinical analysis to estimate iodine concentration in the body), 2 billion of persons worldwide are at risk of insufficient iodine intake [5] and around one third of the world's population lives in areas where natural sources of iodine are low [4]. The World Health Organization (WHO) and UNICEF, recommended universal salt iodization, in 1993, recognizing the need to prevent the iodine deficiency disorders (IDD) [6]. Salt iodization has been implemented in more than 120 countries and could be a feasible option for preventing iodine deficiency on a global scale. In fact, many of these countries have successfully eliminated IDD or made a considerable progress in their control, principally as a result of salt iodization [4]. In 2003 the WHO and the Food and Agriculture Organization of the United Nations (FAO) recommended the reduction of salt intake and food content by less than $5 \mathrm{~g} /$ day, ensuring the adequate salt iodization. Since 2010 this action was accelerated to reduce blood pressure and risk of cardiovascular disease in adults caused by excessive consumption of salt in the diet. The outcomes of salt consumption reduction might help re-emerge the iodine deficiency disorders in some countries [7].

The population diet improvement includes strategies as habits education, public health, dietary diversification, food fortification and supplementation [5]. An adequate diet should supply quantities of micronutrients, energy, protein, essential fat acids and other food constituents required for optimal health, including 
iodine [5]. Many marine resources are known as functional foods [8]. Among those, the seaweeds highlights, since they are rich in unique bioactive compounds which are absent in terrestrial food sources [9]. These compounds include proteins rich in essential amino acids, polyphenols; PUFAs and polysaccharides, that can be used for mankind nutrition [9]. The seaweeds are also a rich source of several essential minerals, that includes, among others, iodine [8]. Some seaweeds have been regularly used for medical and food purposes for centuries in Japan, Korea and China [10]. In China, Laminaria japonica, is use as a dietary iodine supplement to prevent goiter. Also, Laminaria digitata is used as a supplement for myxedema and for goiter treatment [11]. There is a clear evidence that seaweeds consumption increases iodine levels in humans. The measurement of the serum levels of thyroid hormones in combination with well-defined ingestion rates of Saccharina japonica, showed that the urinary excretion of iodine increased [12] A regular seaweeds ingestion can assure the iodine recommend daily intake, representing a food supplement that can improve the nutritive value of a healthy diet [10]. On the other hand, similar with other foods, excess of iodine can be harmful, since it can induce either to hyperthyroidism. The high levels of iodine in some brown macroalgae and their overconsumption could be unhealthy [12].

The iodine in edible plants is originate exclusively from the soil uptake and about $80 \%$ of iodine in the humans and animals derive from this kind of food [13]. Different approaches have been developed to guarantee a better iodine intake for man. Studies shown a significant improvement of iodine concentration in vegetables when they were cultivated using algae organic iodized fertilizer (L. japonica). So, the algae fertilization provides macro and micronutrients for biofortification, improving the soil edaphic properties [2]. Another approach to mitigate the iodine deficiency is the use of seaweeds in animal feed. Freshwater fishes feeding with L. digitata results in a significant increase of the animal's iodine content. Volunteers that fed on the fish, had their urine measured before and after the fish consumption, being the iodine content higher after the ingestion [14]. Growth of rainbow trout, with red seaweed Gracilaria vermiculophylla showed that iodine contents in the fish flesh doubles in relation to the control [15]. The feeding of hens with Eucheuma spinosum determines the significant increase of iodine concentration in its eggs. Iodine contents in urine also increased after these egg's consumption by 24 volunteers [16]. The lack of iodine is a global concern, and regionally as well. In 2012, Madeira Archipelago studies were carried out to assess the iodine content in 311 children aged between 6 and 12 years and with 196 pregnant women. The results showed that $68 \%$ of the children had iodine deficiency and $92 \%$ of the pregnant women had unsuitable values $(<150 \mu \mathrm{g} / \mathrm{L})(17)$.

These results led to a university-enterprise partnership between University of Madeira (BG ISOPlexis) and UBQ II (Unidade de Bioquímica II), aiming to analyze the use of algae to mitigate this situation. Biochemical composition and antioxidantcapacity of seven seaweeds were analyzed and showed that they were suitable to be label as functional foods production [18]. In this study one seaweed, Asparagopsis taxiformis, aroused interest due to their iodine values. A complementary study was done aiming to determine this algae potential as a source of iodine. The results demonstrated that $A$. taxiformis is a valuable source of bioactive compounds with a great potential to be use as a nutraceutical supplement [19]. Besides the importance of seaweeds consumption in the prevention of iodine deficient, they also demonstrate potential benefits for digestive health, weight management, and chronic disease prevention (cancer, cardiovascular diseases, diabetes and osteoporosis) [9]. The alternatives presented in this mini-review does not have the intention to substitute the salt iodization, on the contrary, comes to aggregate information and possible complement salt iodization programs. In countries were the salt supplemented with iodine is not mandatory, or the population has serious risk regarding saltrelated diseases, seaweeds are an effective alternative for iodine supplementation.

\section{Funding}

This work was supported by the projects Blue Iodine II "Boost Blue economy through market uptake an innovative seaweed bioextract for iodine fortification II" (733552, H2020SMEInst-2016-2017); DemoBlueAlgae "Desenvolvimento de metodologias e optimização dos processos de cultivo e processamento de macroalgas para a industria e economia azul" PROCiência 2020 (M1420-01-0247-FEDER000002) and Madeira PO 14-20, contract

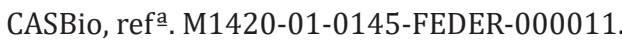

\section{References}

1. Combert E, Ma ZF, Cousins F, Thompson B, Lean MEJ (2014) Low-level seaweed supplementation improves iodine status in iodine- insufficient women. British Journal of Nutrition 112(5): 753-761.

2. Weng HX, Liu HP, Li DW, Ye M, Pan L, et al. (2014) An innovative approach for iodine supplementation using iodine-rich phytogenic food. Environ Geochem Health 36(4): 815-828.

3. WHO (1996) Recommended iodine levels in salt and guidelines for monitoring their adequacy and effectiveness? World Health Organization, Geneva Switzerland.

4. WHO (2014) Guideline: fortification of food-grade salt with iodine for the prevention and control of iodine deficiency disorders? World Health Organization, Geneva, Switzerland.

5. Allen L, Benoist B, Dary O, Hurrell R (2006) Guidelines on food fortification with micronutrients. World Health Organization and Food and Agricultura Organization of the United Nations.

6. WHO (2007) Assessment of iodine deficiency disorders and monitoring their elimination? World Health Organization publication. $3^{\text {rd }}$ edition.

7. WHO (2014) Salt reduction and iodine fortification strategies in public health: report of a joint technical meeting convened by the World Health Organization and The George Institute for Global Health in collaboration with the International Council for the Control of Iodine Deficiency Disorders Global Network? Sydney, Australia: World Health Organization.

8. Shahidi F, Rahman MJ (2018) Bioactives in seaweeds, algae, and fungi and their role in health promotion. J Food Bioact 2: 58-81. 
9. Brown EM, Allsopp PJ, Magee PJ, Gill CIR, Nitecki S, Strain CR, McSorley EM (2014) Seaweed and human health. Nutrition Reviews 72(3): 205216.

10. Kolb N, Vallorani L, Milanovic N, Stocchi V (2004) Evaluation of Marine Algae Wakame (Undaria pinnatifida) and Kombu (Laminaria digitate japonica) as food supplements. Foo Technol Biotechnol 42(1) 57-61.

11. Holdt SL, Kraan S (2011) Bioactive compounds in seaweed: functional food applications and legislation. J Appl Phycol 23(3): 543-597.

12. Wells ML, Potin P, Craigie JS, Raven JA, Merchant SS, et al. (2017) Algae as nutritional and functional food sources: revisiting our understanding. J Appl Phycol 29(2): 949-982.

13. Weng HX, Hong CL, Xia TH, Bao LT, Liu HP, (2013) Iodine biofortication of vegetable plants - An innovative method for iodine supplementation. Chinese Science Bulletin 58(17): 2066-2072.

14. Schmid S, Ranz D, He ML, Burkard S, Lukowicz MV, et al. (2003) Marine algae as natural source of iodine in the feeding of freshwater fish - a new possibility to improve iodine supply of man. Revue Méd Vét 154(10): 645-648.

\section{ISSN: 2574-1241}

DOI: 10.26717/BJSTR.2019.15.002710

Sónia Ferraz. Biomed J Sci \& Tech Res

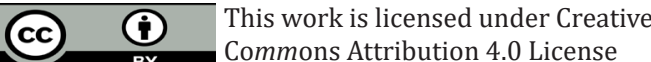

Submission Link: https://biomedres.us/submit-manuscript.php
15. Valente LMP, Rema P, Ferraro V, Pitado M, Pinto IS, et al. (2015) Iodine enrichment of rainbow trout flesh by dietary supplementation with the red seaweed Gracilaria vermiculophylla. Aquaculture 446: 132-139.

16. Kaufmann S, Wolfram G, Delange F, Rambeck WA (1998) Iodine supplementation of laying hen feed: A supplementary measure to eliminate iodine deficiency in humans? Z Ernährungswiss 37(3): 288293.

17. Limbert E, Prazeres S, Madureira D, Miranda A, Ribeiro, M, et al. (2012) Iodine contribution in the Autonomous Regions of Madeira and the Azores. See Port Endoctinol Diabetes Metab 7 (2): 2-7.

18. Nunes N, Ferraz S, Valente S, Barreto MC, Pinheiro de Carvalho MAA (2017) Biochemical composition, nutritional value, and antioxidante properties of seven seaweed species from the Madeira Archipelago. J Appl Phycol 29(5): 2427-2437.

19. Nunes N, Valente S, Ferraz S, Barreto MC, Pinheiro de Carvalho MAA (2018) Nutraceutical potential of Asparagopsis taxiformis (Delile) Trevisan extracts and assessment of a downstream purification strategy. Heliyon 4(11).

$\begin{array}{ll}\text { BIOMEDICAL } & \text { Assets of Publishing with us } \\ \text { RESEARCHES } & \text { - Global archiving of articles } \\ & \text { - Immediate, unrestricted online access } \\ & \text { - Rigorous Peer Review Process } \\ \end{array}$

